\title{
ОСОБЛИВОСТІ МОДЕЛЮВАННЯ БІЗНЕС-ПРОЦЕСУ «УПРАВЛІННЯ ІНВЕСТИЦІЙНОЮ ПРИВАБЛИВІСТЮ ПІДПРИЕМСТВА»
}

\author{
FEATURES OF BUSINESS PROCESS MODELING \\ "MANAGEMENT OF INVESTMENT ATTRACTIVENESS \\ OF THE ENTERPRISE"
}

\author{
Хринюк Олексій Сергійович \\ кандидат економічних наук, доцент, \\ Національний технічний університет України \\ «Київський політехнічний інститут імені Ігоря Сікорського» \\ ORCID: https://orcid.org/0000-0003-4705-9854 \\ Очеретяна Олександра Вадимівна \\ магістрант, \\ Національний технічний університет України \\ «Київський політехнічний інститут імені Ігоря Сікорського» \\ ORCID: https://orcid.org/0000-0002-8443-5997
}

\author{
Khryniuk Oleksii, Ocheretiana Oleksandra \\ National Technical University of Ukraine \\ «Igor Sikorsky Kyiv Polytechnic Institute»
}

\begin{abstract}
У статті проаналізовано використання процесного підходу сучасними підприємствами. На основі наукових праць вітчизняних та зарубіжних науковців визначено основні групи бізнес-процесів, які реалізовуються та впроваджуються в підприємництві. Виявлено недостатній рівень дослідження бізнес-процесу управління інвестиційною привабливістю та обґрунтовано необхідність його моделювання. Розкрито сутність поняття інвестиційна привабливість підприємства. Проведено розмежування понять інвестиційна діяльність та інвестиційна привабливість. Описано принцип міз-ан-абіму (фp. mise en abyme) інвестиційної привабливості, тобто взаємозалежності інвестиційної привабливості підприємства, галузі, регіону та країни. Розглянуто методологію моделювання бізнес-процесів. Здійснено поетапну побудову ТОР-моделі та моделі ланцюга бізнес-процесу «Управління інвестиційною привабливістю підприємства». Описано структурні елементи цього бізнес-процесу та його особливості.

Ключові слова: бізнес-процес, процесний підхід, моделювання бізнес-процесів, управління інвестиційною привабливістю підприємства, інвестиційна привабливість підприємства.
\end{abstract}

В статье проанализировано использование процессного подхода современными предприятиями. На основе научных трудов отечественных и зарубежных ученых определены основные группы бизнес-процессов, которые реализуются и внедряются в предпринимательстве. Обнаружено недостаточный уровень исследования бизнеспроцесса управления инвестиционной привлекательностью и обосновано необходимость его моделирования. Раскрыта сущность понятия инвестиционная привлекательность предприятия. Проведено разграничение понятий инвестиционная деятельность и инвестиционная привлекательность. Описаны принцип мисс-ан-абиму (фрр. mise en abyme) инвестиционной привлекательности, то есть взаимозависимости инвестиционной привлекательности предприятия, отрасли, региона и страны. Рассмотрена методология моделирования бизнес-процессов. Осуществлено поэтапное построение ТОР-модели и модели цепи бизнес-процесса «Управление инвестиционной привлекательностью предприятия». Описаны структурные элементы этого бизнес-процесса и его особенности.

Ключевые слова: бизнес-процесс, процессный подход, моделирование бизнес-процессов, управление инвестиционной привлекательностью предприятия, инвестиционная привлекательность предприятия.

The purpose of the scientific article is to study the essence of investment attractiveness of the enterprise, substantiate the feasibility of separating the management of investment attractiveness of the enterprise as an independent business process, as well as its modeling with an accompanying description of all structural elements. First, 
the article analyzes the use of the process approach by modern enterprises. An in-depth analysis of the scientific works of domestic and foreign scientists was conducted. It was found that companies typically implement and implement only those business processes that are defined in ISO 9001 "Quality Management Systems" and APQC's International Benchmarking Clearinghouse. Among these business processes, no one would directly describe the investment activities of the enterprise, much less any business process that would describe the investment attractiveness of the enterprise. It is determined that the investment activity is the last stage in the business process chain of investment management of the enterprise, as it is preceded by informational, analytical, and strategic stages. The article describes the principle of miz-an-abim investment attractiveness, ie the interdependence of investment attractiveness of the enterprise, industry, region, and country. This should be reflected in the business process model. The methodology of business process modeling is considered in the article. The authors carried out a stepby-step construction of the TOP model and the business process chain model "Management of investment attractiveness of the enterprise". The main structural elements of the business process are described (input sources, input streams, management standards, resources, output streams, and thread recipients). The key feature of the business process of managing the investment attractiveness of the enterprise is its cyclicity. According to the concept of "research actions", it is due to its cyclical nature that the business process can independently improve and increase the efficiency of its work, ie without the intervention of senior management.

Keywords: business process, process approach, business process modeling, management of investment attractiveness of the enterprise, investment attractiveness of the enterprise.

Постановка проблеми. Сучасні підприємства фрункціонують в жорстких умовах конкурентного ринку. Ключовим елементом есрективності ведення підприємницької діяльності стає постійне вдосконалення бізнес-процесів. Це включає як і аналіз діючих бізнес-процесів, пошук шляхів їх оптимізації та вдосконалення, так і впровадження нових. Такий процесний підхід до управління організацією наводиться у вимогах Міжнародного стандарту ISO 9001 «Системи управління якістю» [1].

Підприємства, що впровадили у свою роботу стандарт ISO 9001, мають змогу створити таку систему менеджменту, що дозволяє управляти організацією як сукупністю ефективних бізнес-процесів. Іншими словами, попри цільність організації, менеджери різних рівнів можуть удосконалювати підконтрольні їм бізнес-процеси, не заважаючи роботі інших.

Для покращення діючих та впровадження нових бізнес-процесів необхідні певні інвестиції. Зазвичай вони використовуються для вдосконалення виробничих бізнес-процесів (модернізація обладнання, введення нових технологій тощо) або для загального розвитку підприємства та представлення його на ринку. Важливо зауважити, що в межах стандарту ISO 9001 не розглядаються бізнес-процеси, що пов'язані з інвестиційною діяльністю чи формуванням інвестиційної привабливості підприємства.

Схожий підхід простежується в «Системі класифрікації процесів» розробленій APQC's International Benchmarking Clearinghouse [2]. Наведений у ній перелік бізнес-процесів підприємства поділяється на дві групи: операційні бізнес-процеси (дослідження ринку споживачів, створення стратегії підприємства, розробка продукту чи послуги, планування продажів, виробництво товарів або надання послуг, додаткові сервіси, розрахункові операції з клієнтами), а також бізнес-процеси управління та підтримки (керування та управління людськими, інфрормаційними, фрінансовими, матеріальними, екологічними ресурсами, зовнішніми відносинами та змінотворчі процеси). В межах цієї класифрікації управління інвестиційною привабливістю підприємства можна моделювати лише в загальному вигляді як елемент створення стратегії підприємства або деталізувати за напрямками інвестиційних проєктів та розглядати їх окремо згідно з відповідними бізнес-процесами.

Попри те, що питання організації бізнеспроцесів підприємства досліджували багато зарубіжних та українських науковців, управління інвестиційною привабливістю підприємства як бізнес-процес не розглядається в їхніх наукових працях. Наприклад, Денисенко Л.О. та Шацька С.Є. запропонували класифрікувати бізнес-процеси на основні та допоміжні, серед яких обслуговуючі, управлінські та бізнес-процеси розвитку [3]. До останньої підгрупи відносять бізнес-процеси, які спрямовані на створення інвестиційних проєктів та обґрунтування їхньої доцільності. Бізнеспроцеси розвитку у цій класисрікації розглядаються як чіткі плани для реалізації разових та обмежених у часі дій по модернізації обладнання, диореренціації продукції, виходу на новий ринок тощо.

Андрушків Б.М. та Мельник Л.М. розглядають окремо операційні, забезпечуючі, допоміжні та управлінські бізнес-процеси. В межах забезпечуючих науковці виділяють бізнес-процес залучення інвестицій [4]. В організаційній 
системі управління саме цей процес виступає в ролі постачальника для реалізації основних процесів та підтримує інфрраструктуру підприємства на належному рівні. Хоча Андрушків Б.М. та Мельник Л.М. одні із небагатьох, хто виділив інвестиційну діяльність як окремий бізнес-процес, але навіть при такому підході вони не розглядають систему управління інвестиційною привабливістю підприємства.

Отже, моделювання бізнес-процесів $\epsilon$ широко досліджуваною темою в науковій літературі, але зазвичай вона обмежується розглядом лише тих бізнес-процесів, які визначені ISO 9001 «Системи управління якістю» або APQC's International Benchmarking Clearinghouse. Це зумовлює необхідність розробки нових бізнес-процесів та впровадження їх у діяльність підприємств, що може надати їм значну конкурентну перевагу. Одним із таких бізнес-процесів повинно бути управління інвестиційною привабливістю підприємства, що є першочерговим елементом у здійсненні інвестиційної діяльності та розробці інвестиційних проєктів.

Аналіз останніх досліджень і публікацій. Сутність процесного підходу та узагальнена структура будь-якого бізнес-процесу визначена Міжнародним стандартом ISO 9001 «Системи управління якістю» [1]. Також важливе місце у формуванні системи бізнес-процесів організації займає «Система класифікації процесів» розроблена APQC's International Benchmarking Clearinghouse [2].

Проблеми вдосконалення бізнес-процесів підприємства розглядали сучасні зарубіжні вчені, такі як А. Кераматі, Х.Р. Голіан, М. Афршарі-Мофрад [15] та інші. Серед вітчизняних науковців моделюванням бізнес-процесів займалися 3.М. Гадецька [14], В.О. Коюда [13], В.В. Нетепчук [12], М.І. Пасько [13], М. О. Холопова [14], а формуванням системи бізнес-процесів та класифікуванням бізнеспроцесів - Б.М. Андрушків [4], Л.О. Денисенко [3], Л.М. Мельник [4], С.Є. Шацька [3] та інші.

Дослідження сутності інвестиційної привабливості підприємства розкривається у наукових роботах зарубіжних вчених Г. Дзвігола [10], Я. Бінди [9]. На необхідності оцінки інвестиційної привабливості промислових підприємств наголошували М. Прокопенко, А. Рамський, О. Шуплат, Л. Халан та Д. Михайленко [9]. В межах даного дослідження важливим також є розгляд інвестиційної привабливості на макрорівні рівні (галузь, регіон, країн) та дослідження його зв'язків з мікрорівнем (підприємство). Інвестиційну привабливість на рівні країни вивчали Л. Іванченкова, О. Карташова, І. Кичко, Ю. Мельник, Т. Овчаренко, Л. Шинкарчук [5], на рівні регіону - Є.О. Воробйов [8], О. Алейнікова, Я. Пушак, Ю. Уманська, Н. Шмиголь [10], на рівні галузі - Ю. Алескерова, 3. Титенко, Х. Скрипник, О. Грицина [6].

Управління інвестиційною привабливістю як елемент менеджменту розглядали Л.Ф. Чумак [7; 11], І.В. Пугач [7] та М.М. Івченко [11]. Однак, вони не досліджували його структуру та не моделювали як бізнес-процес, хоча дослідження підпроцесів, нормативів управління, вхідних та вихідних потоків є ключовою умовою для ефективного управління. Отже, попри значний внесок вітчизняних та зарубіжних вчених в дослідження бізнес-процесів та окремо інвестиційної привабливості підприємства, досі залишаються невирішені проблеми, зокрема, моделювання бізнес-процесу управління інвестиційною привабливістю підприємства.

Формулювання цілей статті. Метою статті $€$ виявлення сутності інвестиційної привабливості підприємства, обґрунтування доцільності виокремлення «управління інвестиційною привабливістю підприємства» як самостійного бізнес-процесу, а також його моделювання разом з описом усіх структурних елементів.

Виклад основного матеріалу дослідження. Для розуміння сутності поняття «інвестиційна привабливість» розглянемо його складники. Інвестиції в загальному розумінні - це вкладання ресурсів з метою отримання вигоди. Слово привабливість застосовується для позначення властивості об'єкта викликати інтерес та захоплення. Звідси, інвестиційна привабливість - це здатність підприємства, галузі, регіону чи країни звернути на себе увагу інвестора та викликати в нього бажання інвестувати.

Шинкарук Л., Іванченкова Л. та їхні колеги [5] називають досягнення високого рівня інвестиційної привабливості «ефектом поштовху» для економічного зростання підприємства та умовою його подальшого розвитку.

В науковій літературі також сорормований підхід до розуміння інвестиційної привабливості як досягнення бажаного рівня показників, що її вимірюють [6; 7]. Важливо зазначити, що існує значна кількість методологій, які використовують зовсім різні системи показників.

На основі аналізу наукової літератури можна сорормувати власне визначення інвестиційної привабливості підприємства, окресливши його як сукупність суттєвих характеристик підприємства, які можна виявити за 
допомогою відповідних аналітичних показників, що формують в інвестора позитивний образ про підприємство та спонукають здійснювати вкладення ресурсів в подальший його розвиток.

Інвестиційна привабливість підприємства визначається не лише внутрішніми, а й зовнішніми фракторами. Вона залежить від макроекономічної ситуації в регіоні, галузі, країні та навіть в світі. Такий підхід до розуміння інвестиційної привабливості можна назвати міз-ан-абімом (фpp. mise en abyme), або простіше «принципом матрьошки». Отже, інвестиційна привабливість країни впливає на інвестиційну привабливість регіонів та галузей, а вони в свою чергу на інвестиційну привабливість підприємств [8; 9; 10].

В межах даного дослідження також варто розмежувати поняття «інвестиційна привабливість» та «інвестиційна діяльність». Друге використовується для позначення дій підприємства, пов'язаних з безпосереднім вкладанням або одержанням коштів від інвесторів. Згідно з розумінням етапів управління інвестиційною привабливістю підприємства Чумак Л.Ф. визначає здійснення інвестиційної діяльності кінцевою фазою у цьому процесі [11].

Моделювання будь-якого бізнес-процесу передбачає дотримання певної процедури. На першому етапі визначається мета проєктування моделі. Далі будується ТОР-модель бізнес-процесу, тобто визначаються усі структурні елементи: джерела входів, вхідні потоки, нормативи управління, ресурси, вихідні потоки та одержувачі потоків (рис. 1). На третьому етапі проєктується ланцюг бізнес-процесу, тобто деталізуються усі етапи реалізації процесу. Останній етап - це перевірка ефрективності моделі та внесення коректив у разі необхідності [12].
Згідно з описаною методологією проведемо моделювання бізнес-процесу.

I. Як уже зазначалося у роботі, метою моделювання бізнес-процесу управління інвестиційною привабливістю підприємства може бути створення конкурентних переваг, залучення та/або зацікавлення нових інвесторів, успішна реалізація інвестиційної програми тощо.

II. ТОР-модель бізнес-процесу «Управління інвестиційною привабливістю підприємства представлена на рис. 2. Ії̈ структурні елементи [12; 13]:

1) вхідні потоки представляють собою матеріали, інформацію, ресурси для повного використання в процесі тощо. В даній моделі це інорормація для аналізу інвестиційної привабливості підприємства, галузі, регіону та країни;

2) нормативи управління - це перелік документів, якими керується підприємство під час організації роботи. Для управління інвестиційною привабливістю це може бути загальна законодавча база, стратегія розвитку підприємства і при наявності інвестиційна програма, політика чи стратегія;

3) ресурси - фрактори, що не транссрормуються у кінцевий продукт (наприклад, людські ресурси). У даному моделюванні це персонал підприємства, управлінський підхід та вкладення інвестора;

4) вихідні потоки - результат бізнес-процесу. При здійсненні ефективного управління інвестиційною привабливістю підприємства досягається високий рівень інноваційноінвестиційного розвитку підприємства, а також здійснюється макроекономічний вплив на галузь, регіон та країну.

5) джерела входів - це попередні процеси. Наприклад, на деяких підприємствах управ-

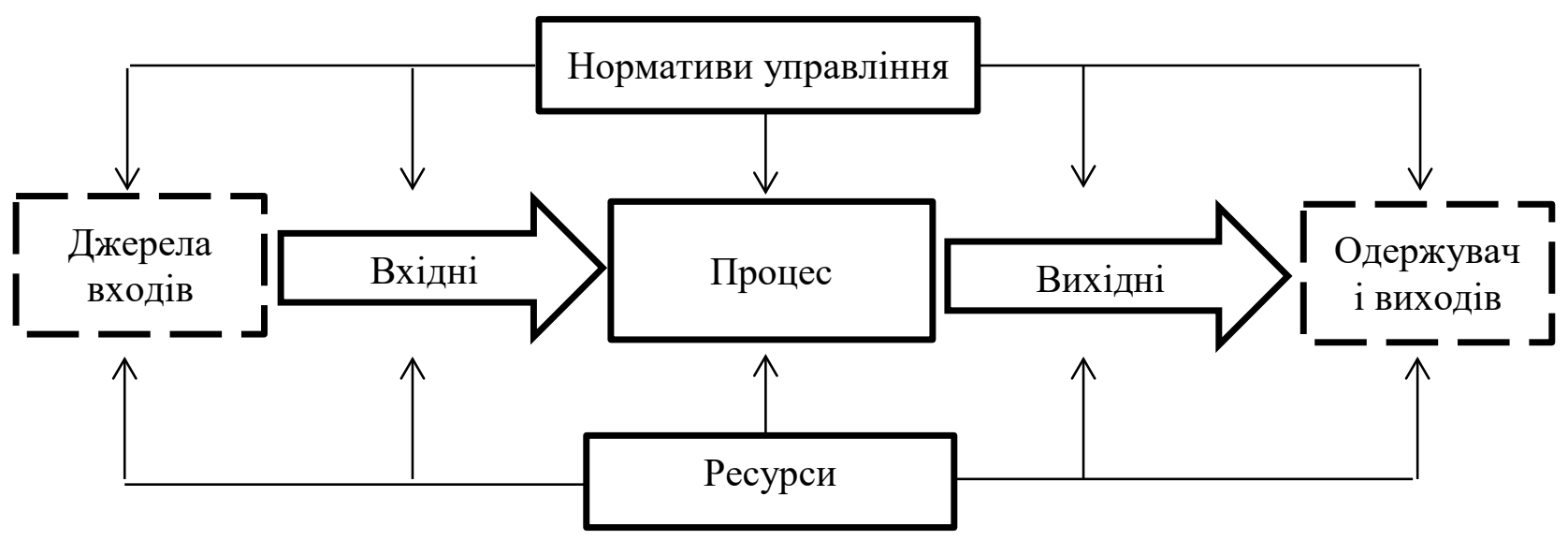

Рис. 1. Загальна схема моделювання бізнес-процесів Джерело: розроблено автором на онові [1; 12] 


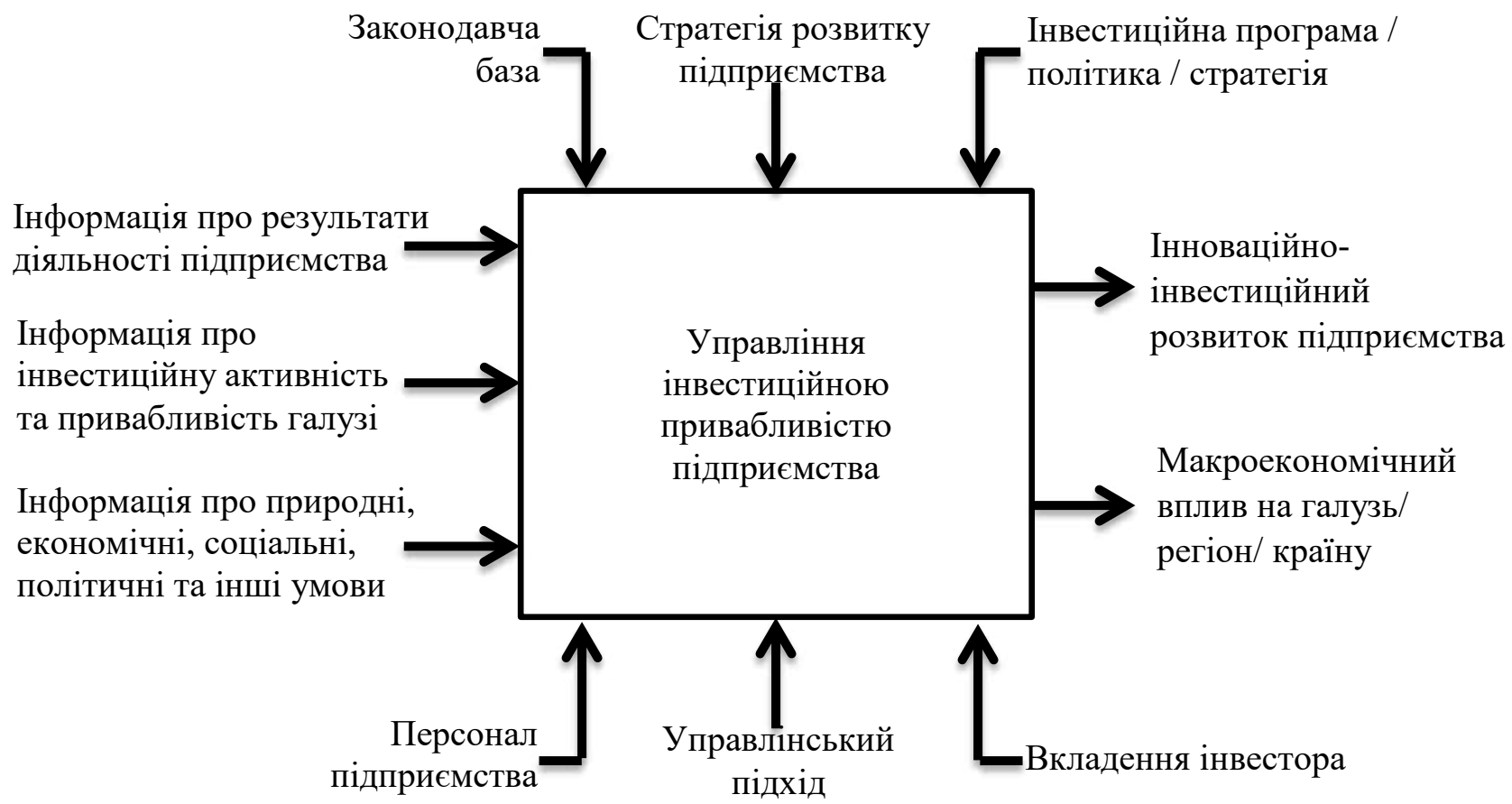

Рис. 2. ТОР-модель бізнес-процесу «Управління інвестиційною привабливістю підприємства» Джерело: розроблено автором на основі [7; 12; 14]

лінню інвестиційною привабливістю підприємства може передувати створення програми розвитку або управлінське рішення.

6) одержувачі виходів - це наступні процеси. Після формування інвестиційної привабливості логічним $є$ залучення інвесторів, розробка інвестиційних проєктів або підвищення ефективності роботи інших бізнес-процесів.

III. Модель ланцюга бізнес-процесу «Управління інвестиційною привабливістю підприємства» будується як розкриття ТОРмоделі, тобто деталізація етапів здійснення управління з використанням уже визначених структурних елементів (рис. 3). Ланцюг бізнес-процесу розпочинається 3 інсрормаційних процесів, тобто аналізу поточного стану діяльності підприємства, а також інвестиційного потенціалу галузі та інвестиційного клімату в регіоні/ країні. Як уже зазначалося, це необхідно для дотримання принципу міз-анабіму, тобто дослідження усіх ендогенних та екзогенних впливів. Наступною складовою ланцюга $€$ реалізація аналітичних процесів, тобто визначення фракторів, пошук резервів та аналіз ризиків управління інвестиційною привабливістю підприємства. Така діагностика необхідна для планування заходів щодо підвищення рівня інвестиційної привабливості підприємства, розробки інвестиційної стратегії в разі її відсутності, розширення інвестиційної програми тощо. Обов'язковим елементом ланцюга є прогнозування очікуваних результатів. На цьому етапі переглядаються встановлені на початку управління цілі, а також встановлюються обґрунтовані межі планового розвитку. Завершує ланцюг бізнес-процесу безпосереднє здійснення інвестиційної діяльності. Після цього підприємство може оцінити отриманий есрект та при необхідності внести корективи для управління інвестиційною привабливістю в майбутніх періодах.

Особливістю ланцюга бізнес-процесу «Управління інвестиційною привабливістю підприємства» $є$ його циклічність. А. Кераматі, Х.Р. Голіан та М. Асршарі-Мофррад розглядають ії в межах концепції «дії досліджень» (англ. action research). Таким чином, циклічність постає способом організації управління бізнес-процесом, у якому учасники регулярно аналізують власну діяльність, так як розуміння процесів в учасників, згідно 3 даною концепцією, формується лише в момент безпосередньої реалізації цих процесів [15].

Головною перевагою концепції «дії досліджень» при управлінні інвестиційною привабливістю підприємства можна вважати створення системи, яка самостійно вдосконалюється. Мається на увазі, що учасники бізнес-процесу одразу усвідомлені та зацікавлені у пошуку проблем чи неефективних рішень у виконаній роботі для підвищення власної експертності та досягнення кращих 


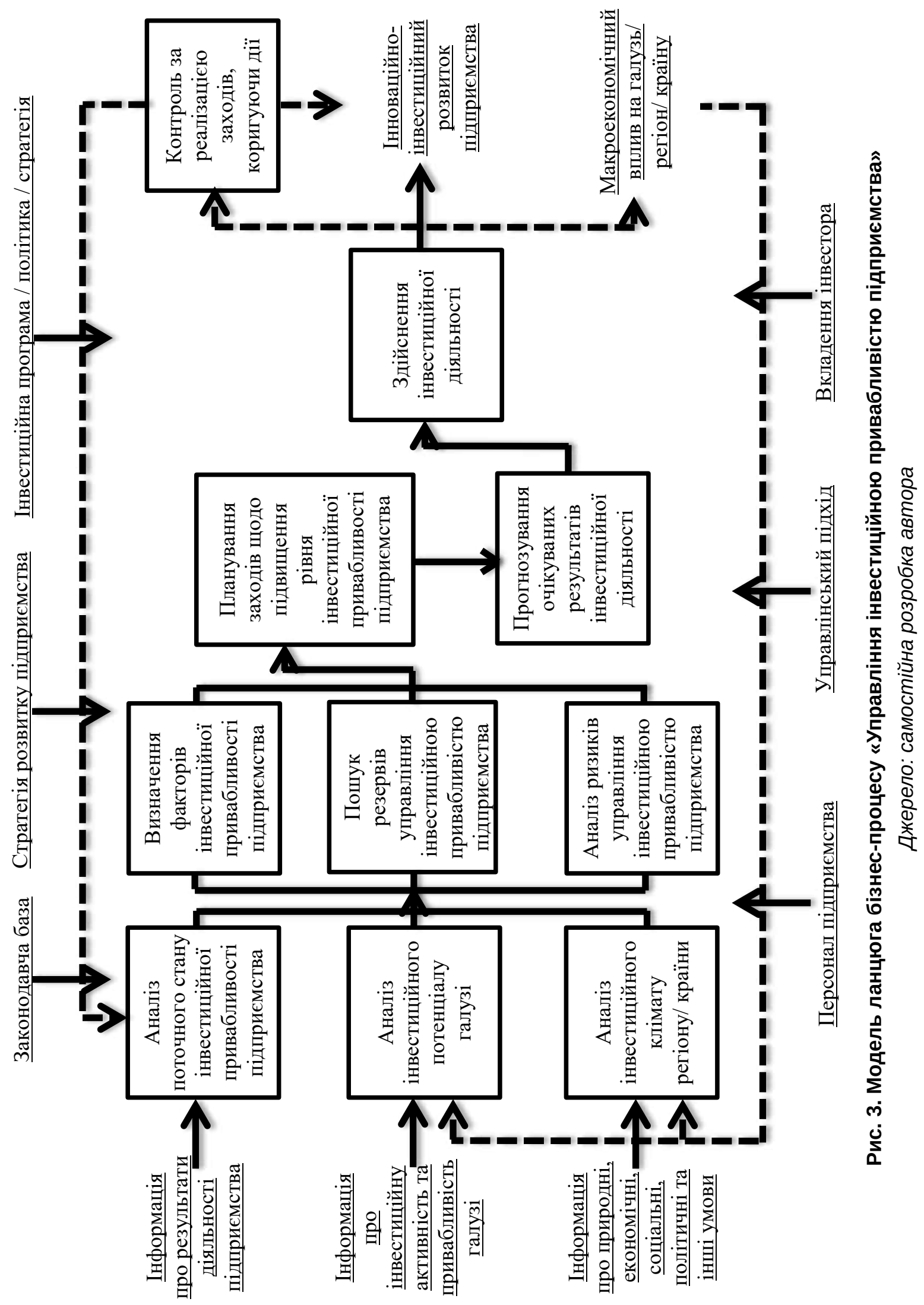


результатів в майбутньому. Такий бізнес-процес не потребує додаткового втручання керівництва та залучення зовнішніх ресурсів для покращення роботи.

Висновки. Процесний підхід дістає все більшого поширення у сучасному бізнесі. При цьому, зазвичай, підприємства використовують у своїй діяльності бізнес-процеси, які запропоновані ISO 9001 «Системи управління якістю» або APQC's International Benchmarking Clearinghouse. Однак серед них немає жодної моделі управління інвестиційною-привабливістю підприємства. Наразі деякі вітчизняні вчені пропонують розглядати моделі бізнес-про- цесів інвестиційної діяльності, але це не враховує інформаційних, аналітичних та стратегічних процесів, що їй передують. Наукова новизна дослідження полягає у створенні ТОР-моделі та моделі ланцюга бізнес-процесу «Управління інвестиційною привабливістю підприємства». У статті доведена необхідність впровадження цього бізнес-процесу у діяльність будь-якого підприємства та обґрунтовані підходи до моделювання. Запропоновані моделі мають велике практичне значення для впровадження та реалізації у підприємницькій діяльності, а також теоретичну значущість для подальших наукових досліджень у цьому напрямку.

\section{СПИСОК ВИКОРИСТАНИХ ДЖЕРЕЛ:}

1. ДСТУ ISO 9001:2015 «Системи управління якістю». ДП «УкрНДНЦ». Київ, 2016. URL: https://khoda.gov.ua/ image/catalog/files/\%209001.pdf

2. Система класифрікації процесів. APQC's International Benchmarking Clearinghouse. URL: http://or-rsv.narod.ru/ Docs/ProcessClassificationFramework.pdf

3. Денисенко Л.О., Шацька С.Є. Концептуальні засади класифікації бізнес-процесів, як основи формування бізнес-системи організації. Ефрективна економіка. 2012. № 11. URL: http://nbuv.gov.ua/UJRN/efek_2012_11_34

4. Андрушків Б.М., Мельник Л.М. Формування системи бізнес-процесів підприємства у контексті сталого розвитку. Теоретичні і практичні аспекти економіки та інтелектуальної власності. 2015. Вип. 2(1). С. 91-97.

5. Shynkaruk L., Ivanchenkova L., Kychko I., Kartashova O., Melnyk Y., Ovcharenko T. Managing the Economy's Investment Attractiveness of the State as a Component of International Business Development. International Journal of Management. 2020. № 11(5), pp. 240-251.

6. Aleskerova Y., Titenko Z., Skrypnyk H., Grytsyna O. Modeling The Level Of Investment Attractiveness Of The Agrarian Economy Sector. International Journal of Industrial Engineering \& Production Research. 2020. Vol. 31. № 4. Pp. 647-653.

7. Чумак Л.Ф., Пугач І.В. Підходи до аналізу управлінського аспекту інвестиційної привабливості підприємства. Вісник економіки транспорту і промисловості. 2015. Вип. 49. С. 181-184.

8. Воробйов $€$. О. Фактори та умови фрормування інвестиційної привабливості підприємства. Науковий вісник УМО. Серія : Економіка та управління. 2016. Вип. 2. URL: http://nbuv.gov.ua/UJRN/nvumo_2016_2_15

9. Binda J., Prokopenko M., Ramskyi A., Shuplat O., Halan L., Mykhaylenko D. Assessment Of Investment Attractiveness Of Industrial Enterprises. International Journal of Management (IJM). 2020. Vol. 11. Issue 2. Pp. 27-35.

10. Dzwigol H., Aleinikova O., Umanska Y., Shmygol N., Pushak Y. An Entrepreneurship Model for Assessing the Investment Attractiveness of Regions. Journal of Entrepreneurship Education. 2019. Vol. 22, Special Issue. URL: https://www.abacademies.org/articles/an-entrepreneurship-model-for-assessing-the-investment-attractivenessof-regions-7908.html

11. Чумак Л.Ф., Івченко М.М. Управління інвестиційною привабливістю підприємств. Бізнес Інфрорм. 2018. № 9. С. 71-76.

12. Нетепчук В.В. Управління бізнес-процесами : Навч. посібник. Рівне : НУВГП, 2014. 158 ст.

13. Коюда В.О., Пасько М.І. Бізнес-процеси сучасного промислового підприємства. Бізнес Інфрорм. 2018. № 1. С. 302-311.

14. Гадецька 3. М., Холопова М.О. Моделювання бізнес-процесів діяльності підприємства. Ефективна економіка. 2016. № 5. URL: http://nbuv.gov.ua/UJRN/efek_2016_5_12

15. Keramati A., Golian H., Afshari-Mofrad M. Improving business processes with business process modelling notation and business process execution language: an action research approach. International Journal of Business Information Systems. 2011. № 7. Issue 4. Pp. 458-476.

\section{REFERENCES:}

1. ISO 9001:2015 "Quality management systems - Requirements", IDT (2016). Kyiv: DP «UkrNDNTs». Available at: https://khoda.gov.ua/image/ catalog/files/\%209001.pdf (in Ukrainian) 
2. Process Classification Framework. APQC's International Benchmarking Clearinghouse. Available at: http://or-rsv.narod.ru/Docs/ProcessClassification Framework.pdf

3. Denysenko L.O., Shatska S.le. (2012) Kontseptualni zasady klasyfikatsii biznes-protsesiv, yak osnovy formuvannia biznes-systemy orhanizatsii [Conceptual bases of classification of business processes as bases of formation of business system of the organization]. Efektyvna ekonomika (electronic journal), vol. 11. Available at: http://nbuv.gov.ua/UJRN/ efek_2012_11_34

4. Andrushkiv B.M., Melnyk L.M. (2015) Formuvannia systemy biznes-protsesiv pidpryiemstva u konteksti staloho rozvytku [Forming a system of business processes of the enterprise in the context of sustainable development]. Teoretychni i praktychni aspekty ekonomiky ta intelektualnoi vlasnosti, vol. 2(1), pp. 91-97.

5. Shynkaruk L., Ivanchenkova L., Kychko I., Kartashova O., Melnyk Y., Ovcharenko T. (2020) Managing the Economy's Investment Attractiveness of the State as a Component of International Business Development. International Journal of Management, vol. 11(5), pp. 240-251.

6. Aleskerova Y., Titenko Z., Skrypnyk H., Grytsyna O. (2020) Modeling The Level Of Investment Attractiveness Of The Agrarian Economy Sector. International Journal of Industrial Engineering \& Production Research, vol. 31, no. 4, pp. 647-653.

7. Chumak L.F., Puhach I.V. (2015) Pidkhody do analizu upravlinskoho aspektu investytsiinoi pryvablyvosti pidpryiemstva [Approaches to the analysis of the managerial aspect of investment attractiveness of the enterprise]. Visnyk ekonomiky transportu i promyslovosti, vol. 49, pp. 181-184.

8. Vorobiov Ye. O. (2016) Faktory ta umovy formuvannia investytsiinoi pryvablyvosti pidpryiemstva [Factors and conditions of formation of investment attractiveness of the enterprise]. Naukovyi visnyk UMO. Seriia: Ekonomika ta upravlinnia (electronic journal), vol. 2. Available at: http://nbuv.gov.ua/UJRN/nvumo_2016_2_15

9. Binda J., Prokopenko M., Ramskyi A., Shuplat O., Halan L., Mykhaylenko D. (2020) Assessment Of Investment Attractiveness Of Industrial Enterprises. International Journal of Management (IJM), vol. 11, issue 2, pp. 27-35.

10. Dzwigol H., Aleinikova O., Umanska Y., Shmygol N., Pushak Y. (2019) An Entrepreneurship Model for Assessing the Investment Attractiveness of Regions. Journal of Entrepreneurship Education (electronic journal), vol. 22, Special Issue. Available at: https://www.abacademies.org/articles/an-entrepreneurship-model-for-assessing-the-investment-attractiveness-of-regions-7908.html

11. Chumak L. F., Ivchenko M. M. (2018) Upravlinnia investytsiinoiu pryvablyvistiu pidpryiemstv [Management of investment attractiveness of enterprises]. Biznes Inform, vol. 9, pp. 71-76.

12. Netepchuk V.V. (2014) Upravlinnia biznes-protsesamy [Business process management]: Tutorial. Rivne: NUVHP. (in Ukrainian)

13. Koiuda V.O., Pasko M.I. (2018) Biznes-protsesy suchasnoho promyslovoho pidpryiemstva [Business processes of a modern industrial enterprise]. Biznes Inform, vol. 1, pp. 302-311.

14. Hadetska Z. M., Kholopova M.O. (2016) Modeliuvannia biznes-protsesiv diialnosti pidpryiemstva [Modeling of business processes of enterprise activity]. Efektyvna ekonomika, vol. 5. Available at: http://nbuv.gov.ua/UJRN/ efek_2016_5_12

15. Keramati A., Golian H., Afshari-Mofrad M. (2011) Improving business processes with business process modelling notation and business process execution language: an action research approach. International Journal of Business Information Systems, vol. 7, issue 4, pp. 458-476. 